\title{
Experiencing of domestic violence during childhood and level of per- sonality trait of anxiety in adults
}

\author{
Doświadczanie przemocy domowej w dzieciństwie a poziom osobowościowej cechy lęku u \\ osób dorosłych
}

\author{
Bernarda Bereza ${ }^{1}$, Justyna Morylowska-Topolska², Anna Urbańska ${ }^{3}$, \\ Diana Szymczuk ${ }^{3}$, Hanna Karakuła-Juchnowicz ${ }^{4}$ \\ ${ }^{1}$ Chair of Clinical Psychology, The John Paul II Catholic University of Lublin \\ 2 Department of Clinical Neuropsychiatry, Medical University of Lublin \\ 3II Department of Psychiatry and Psychiatry Rehabilitation Medical University of Lublin \\ ${ }^{4}$ I Department of Psychiatry, Psychotherapy and Early Intervention Medical University of Lublin
}

\begin{abstract}
Aim. The aim of the study was looking for correlations between experiencing of various forms of harming in childhood and severity of personal trait of anxiety in victims of domestic violence.

Material and methods. The number of 112 people (49 women and 63 men) who were attending the mental health clinics in the area of Mazovian district were investigated. The sociodemographic questionnaire and Polish adaptation of the State-Trait Anxiety Inventory (by C.D. Spielberger) were used.

Results. High severity of anxiety as a trait, more often than low severity correlates with experiencing of violence (physical and mental) during childhood. Most often it is mental violence with father as perpetrator $(p<0.01)$. People with the high level of anxiety as a trait have more often still been experiencing violence, living with their perpetrator and using violence towards other people $(p<0.05)$.

Conclusions. Awareness of psychological consequences of using violence towards the youngest permit to hope for optimization of actions preventing spreading of such pathology (for example therapeutic work with learned helplessness and copying of destructive family patterns).
\end{abstract}

Keywords: anxiety, domestic violence, children

\section{Streszczenie}

CEL. Celem pracy było poszukiwanie zależności między doświadczaniem różnych form krzywdzenia w dzieciństwie a nasileniem osobowościowej cechy lęku u ofiar przemocy domowej.

MATERIAŁ I METODY. W badaniu wzięło udział 112 pacjentów (49 kobiet i 63 mężczyzn) Poradni Zdrowia Psychicznego na terenie województwa mazowieckiego. W badaniach wykorzystano ankietę socjodemograficzną oraz polską adaptację kwestionariusza STAI (C.D. Spielbergera).

WYNIKI. Wysokie nasilenie cechy lęku częściej niż niskie wiąże się z doświadczaniem przemocy (fizycznej i psychicznej) w dzieciństwie, najczęściej przemoc przybiera formy opresji psychicznej, której sprawcą jest ojciec $(\mathrm{p}<0.01)$. Osoby z wysokim poziomem cechy lęku znacząco liczniej nadal doświadczają przemocy, mieszkają ze sprawcami przemocy oraz stosują przemoc wobec innych ( $<<0.05)$.

WNIOSKI. Świadomość psychologicznych konsekwencji stosowania przemocy wobec najmłodszych, pozwala mieć nadzieję na optymalizację działań zapobiegających rozpowszechnianiu patologii (m.in. terapeutyczną pracę z wyuczoną bezradnością oraz powielaniem destrukcyjnych wzorców rodzinnych).

Słowa kluczowe: lęk, przemoc domowa, dzieci

\section{Theoretical background}

The issue of domestic violence has been the object of interest of theorists and investigators for a long time; it moves public opinion and media. According to the statistics including recent years, there are more than 113,500 people in Poland who are touched by domestic violence, and children in the age of $0-13$ constitute close to $20 \%$ of this group [1]. Every year even tens of them die due to various forms of harming [2]. Medical statistics record only few, usually extreme cases of children maltreatment and the set of physical and mental injures arisen as a result of violence is called the syndrome of maltreated child $[2,3]$. A lot of acts of aggression towards the children take place in homes and is never recorded.

From the psychological point of view, the emotional results of living close to the aggressor is mainly enormous 
distress. Childhood is a period of shaping fundamental frameworks of mental structure and human personality [4-6]. Frustration of primary need for security from the individuals who naturally should provide protection (parents and caregivers), especially destructively influences current and later biopsychosocial functioning of children. There are reports about juveniles who were witnesses or victims of violence, and as a result of it, they are mentally disturbed. We can observe persistent fear, learned helplessness, fixed attitude of hostility, low self-estimation, problems with control of emotions, difficulties in interpersonal relationships and intrusive thoughts [7-9]. Juvenile victims of domestic violence more often suffer from depression and various kinds of somatization and even resignation reactions and suicidal attempts [7]. The last ones, considered as a form of acting-out (emotions played in behavior), are the expression of inappropriate regulation of emotions, noncoping with stress and need of social support.

\section{Aim}

The aim of the work was looking for correlations between experiences of various forms of harming in childhood and severity of personality trait of anxiety in the group of domestic violence victims. We compared people with high and low level of anxiety as a trait in the field of: experienced forms of violence, perpetrators (sources of violence), emotions appearing in reaction to experienced violence and current life situation (current contact with perpetrator and using violence).

\section{Material and method}

\section{Investigated persons}

Research methods were given to 147 patients attending the mental health clinics in the area of Masovian district ${ }^{1}$. Inclusion criteria were trauma of violence in childhood and lack of significant mental disorders (absence of psychiatric treatment in history). Participation in the study was voluntary, anonymous, under the rules of ethical code of psychologist. Extreme groups were formed from respondents group using method of quantiles: the group with the highest results concerning severity of anxiety as a trait (investigated group, $\mathrm{N}=79$ ) and with the lowest results (control group, $\mathrm{N}=33$ ). Ultimately statistical analyses comprised 112 individuals (49 women and 63 men), the age of these people was between 18 and 59 years old (the average age was 36 ). Detailed sociodemographic description of the group was presented in Table 1.

In the study group there were people often unmarried (46.8\%), living in cities with more 100000 dwellers (48.1\%), with secondary (35.4\%) and occupational

\footnotetext{
${ }^{1}$ The study was performed by Jolanta Burdas
}

(27.8\%) level of education and with poor financial income (29.5\%). The control group consisted of people rather living with partner (36.4\%) and families (57.6\%), with secondary (39.4\%) and higher (27.3\%) level of education, more often living in small towns (34.4\%) and with rather good financial situation (45.5\%). As far as controlled sociodemographic variables are concerned, the groups did not differ statistically. The only significant difference was occupational state. In the studied group people more often had no job $(21.5 \%)$ or were retired $(17.7 \%)$ and in the control group individuals more often had work $(63.6 \%)$ or were improving their professional qualifications $(24.2 \%)\left(\chi^{2}=15.604 ; \mathrm{df}=4 ; p=0.004\right)$.

\section{Investigational measures}

We used personal questionnaire and the State-Trait Anxiety Inventory STAI by C.D.Spielberger, R.L.Gorsuch and R.E.Lushene - in the Polish adaptation by

J.Strelau, M.Tysarczyk and K.Wrześniewski (in Polish STAI Inwentarz Stany i Cechy Lęku, ISCL).

The questionnaire consisted of 17 questions. For the needs of this work, apart from the part gathering sociodemographic data (9 items), we also asked about forms of experienced violence, sources of violence, emotional reactions of victims in view of experienced violence and current life situation (contact with the aggressor and using violence).

The Polish version of STAI consists of two parts, each with 20 questions. The first part regards the assessment of anxiety as a state (emotion felt in the moment) and the second one - anxiety as a trait (personality predisposition, usually felt). The first part investigates presence of anxiety and the second one - its frequency. Internal agreement ( $\alpha$ Cronbach coefficient) and absolute stability of this method is high (reliability index is more than 0.80) [10].

\section{Methods of statistical analysis}

The results were statistically analysed with the statistical package SPSS for Windows 14.0 PL. Description methods and statistical inference methods were used in working of data. Comparison of average results in the studied groups was preceded by the check of distribution concordance of analysed measurable features with the normal distribution using $\lambda$ Kolmogorov test. Differences importance between groups was tested by t-Student test, $\chi^{2}$ test and U Mann-Whitney test. We took $\mathrm{p}<0.05$ as a border level of differences importance.

\section{Results}

Comparison of experienced forms of violence in persons with high and low level of anxiety as a trait.

Results showed that people with high level of anxiety as a trait experienced significantly different forms of violence in comparison with people with low level of it. 
Table 1. Sociodemographic description of the group $(\mathrm{N}=112)$.

\begin{tabular}{|c|c|c|c|c|c|c|c|c|c|}
\hline & & \multicolumn{2}{|c|}{$\begin{array}{l}\uparrow \text { anxiety } \\
(\mathrm{N}=79)\end{array}$} & \multicolumn{2}{|c|}{$\begin{array}{c}\downarrow \text { anxiety } \\
(\mathrm{N}=33)\end{array}$} & \multicolumn{2}{|c|}{$\begin{array}{c}\text { Total } \\
(\mathrm{N}=112)\end{array}$} & \multicolumn{2}{|c|}{ Difference significance } \\
\hline & & $\mathrm{N}$ & $\%$ & $\mathrm{~N}$ & $\%$ & $\mathrm{~N}$ & $\%$ & $t(d f=1)$ & $\mathrm{p}$ \\
\hline \multirow{2}{*}{ gender } & women & 32 & 40.5 & 17 & 51.5 & 49 & 43.8 & \multirow{2}{*}{1.146} & \multirow{2}{*}{ n.i. } \\
\hline & men & 47 & 59.5 & 16 & 48.5 & 63 & 56.3 & & \\
\hline \multirow{2}{*}{\multicolumn{2}{|c|}{ age }} & $\mathrm{M}$ & SD & $\mathrm{M}$ & SD & $\mathrm{M}$ & SD & $t(d f=110)$ & $\mathrm{p}$ \\
\hline & & 35.18 & 10.73 & 35.72 & 10.32 & 36.34 & 10.57 & 0.244 & n.i. \\
\hline \multicolumn{2}{|c|}{ education } & $\mathrm{N}$ & $\%$ & $\mathrm{~N}$ & $\%$ & $\mathrm{~N}$ & $\%$ & $\chi^{2}(\mathrm{df}=4)$ & $\mathrm{p}$ \\
\hline \multicolumn{2}{|c|}{ primary } & 14 & 17.7 & 4 & 12.1 & 18 & 16.1 & \multirow{5}{*}{4.015} & \multirow{5}{*}{ n.i. } \\
\hline \multicolumn{2}{|c|}{ occupational } & 22 & 27.8 & 7 & 21.2 & 29 & 25.9 & & \\
\hline \multicolumn{2}{|c|}{ secondary } & 28 & 35.4 & 13 & 39.4 & 41 & 36.6 & & \\
\hline \multicolumn{2}{|c|}{ higher } & 12 & 15.2 & 9 & 27.3 & 21 & 18.8 & & \\
\hline \multicolumn{2}{|l|}{ other } & 3 & 3.8 & 0 & 0 & 3 & 2.7 & & \\
\hline \multicolumn{2}{|c|}{ place of living } & $\mathrm{N}$ & $\%$ & $\mathrm{~N}$ & $\%$ & $\mathrm{~N}$ & $\%$ & $\chi^{2}(\mathrm{df}=3)$ & $\bar{p}$ \\
\hline \multicolumn{2}{|c|}{ countryside } & 19 & 24.1 & 10 & 31.1 & 29 & 26.1 & \multirow{4}{*}{3.829} & \multirow{4}{*}{ n.i. } \\
\hline \multicolumn{2}{|c|}{ Town to 50000 citizens } & 18 & 22.8 & 11 & 34.4 & 29 & 26.1 & & \\
\hline Town to & -100000 citizens & 4 & 5.1 & 2 & 6.3 & 6 & 5.4 & & \\
\hline \multicolumn{2}{|c|}{$\begin{array}{l}\text { City with more than } 100000 \\
\text { citizens }\end{array}$} & 38 & 48.1 & 9 & 28.1 & 47 & 42.3 & & \\
\hline \multicolumn{2}{|c|}{ Civil status } & $\mathrm{N}$ & $\%$ & $\mathrm{~N}$ & $\%$ & $\mathrm{~N}$ & $\%$ & $\chi^{2}(\mathrm{df}=5)$ & $\mathrm{p}$ \\
\hline married & & 22 & 27.8 & 12 & 36.4 & 34 & 30.4 & & \\
\hline divorce & & 10 & 12.7 & 1 & 3 & 11 & 9.8 & & \\
\hline separat & & 4 & 5.1 & 4 & 12.1 & 8 & 7.1 & & \\
\hline unmarr & & 37 & 46.8 & 14 & 42.4 & 51 & 45.5 & 4.552 & n.l. \\
\hline in free $r$ & ionship & 3 & 3.8 & 1 & 3 & 4 & 3.6 & & \\
\hline other & & 3 & 3.8 & 1 & 3 & 4 & 3.6 & & \\
\hline Occupat & al status & $\mathrm{N}$ & $\%$ & $\mathrm{~N}$ & $\%$ & $\mathrm{~N}$ & $\%$ & $\chi^{2}(\mathrm{df}=4)$ & $\mathrm{p}$ \\
\hline pupil/st & & 5 & 6.3 & 8 & 24.2 & 13 & 11.6 & & \\
\hline white $\mathrm{cc}$ & worker & 19 & 24.1 & 13 & 39.4 & 32 & 28.6 & & \\
\hline manual & rker & 24 & 30.4 & 8 & 24.2 & 32 & 28.6 & 15.604 & $<0.01$ \\
\hline unempl & & 17 & 21.5 & 4 & 12.1 & 21 & 18.8 & & \\
\hline other & & 14 & 17.7 & 0 & 0 & 14 & 12.5 & & \\
\hline living & & $\mathrm{N}$ & $\%$ & $\mathrm{~N}$ & $\%$ & $\mathrm{~N}$ & $\%$ & $\chi^{2}(\mathrm{df}=2)$ & $p$ \\
\hline with ow & mily & 27 & 34.6 & 19 & 57.6 & 46 & 41.4 & & \\
\hline lonely & & 25 & 32.1 & 8 & 24.2 & 33 & 29.7 & 5.272 & n.i. \\
\hline other & & 26 & 22.5 & 6 & 18.2 & 32 & 28.8 & & \\
\hline & & $\mathrm{M}$ & SD & $\mathrm{M}$ & SD & $\mathrm{M}$ & SD & $\mathrm{t}(\mathrm{df}=110)$ & $\mathrm{p}$ \\
\hline children & & 1.11 & 1.56 & 1.45 & 1.22 & 1.21 & 1.47 & 1.117 & n.i. \\
\hline financia & uation & $\mathrm{N}$ & $\%$ & $\mathrm{~N}$ & $\%$ & $\mathrm{~N}$ & $\%$ & $\chi^{2}(\mathrm{df}=5)$ & $\mathrm{p}$ \\
\hline very go & & 2 & 2.6 & 1 & 3 & 3 & 2.7 & & \\
\hline good & & 15 & 19.2 & 10 & 30.3 & 25 & 22.5 & & \\
\hline rather g & & 24 & 30.8 & 15 & 45.5 & 39 & 35.1 & & \\
\hline rather $b$ & & 23 & 29.5 & 5 & 15.2 & 28 & 25.2 & 6.886 & n.i. \\
\hline bad & & 8 & 10.3 & 1 & 3 & 9 & 8.1 & & \\
\hline very ba & & 6 & 7.7 & 1 & 3 & 7 & 6.3 & & \\
\hline
\end{tabular}

First, people in the studied group more often reported experiencing both physical and mental violence, than people in the control group. Second, people in the studied group more often pointed various forms of mental violence (and less physical one, $\mathrm{p}<0.001$, Tab.2.).

\section{Comparison of the groups concerning perpetrators (sources of violence).}

The results showed that persons with high level of anxiety closely twice more often experienced violence from father (58.2\%) than persons with low level of anxiety $(30.3 \%, \mathrm{p}=0.007))$ and these differences are statistically significant $(p<0.010)$. Despite the fact that differences between the groups regarding other persons using violence seemed to be statistically non- significant, it is noticeable that people with high level of anxiety about twice more often experienced violence also from the siblings, teachers and other persons ("stepfather", "camp caregiver", "caregiver in child care home") than people with low level of anxiety. In some part of respondents in the studied group (7.6\%) the perpetrators were also grandparents (such answers were not noted in the control group, Tab.3.).

\section{Comparison between groups regarding emotion ap- pearing in reaction of experienced violence.}

Important part of the study was the analysis of results in terms of feelings experienced in the past during acts of violence; and also currently for a memory of this trauma. 
Table 2. Differences in forms of experienced violence in the studied groups $(\mathrm{N}=112)$.

\begin{tabular}{|c|c|c|c|c|c|c|c|c|}
\hline \multirow[t]{2}{*}{ Form of violence } & \multicolumn{2}{|c|}{$\begin{array}{l}\uparrow \text { anxiety } \\
(\mathrm{N}=79)\end{array}$} & \multicolumn{2}{|c|}{$\begin{array}{l}\downarrow \text { anxiety } \\
(\mathrm{N}=33)\end{array}$} & \multicolumn{2}{|c|}{$\begin{array}{l}\text { In general } \\
(\mathrm{N}=112)\end{array}$} & \multicolumn{2}{|c|}{ Differences significance } \\
\hline & $\mathrm{M}$ & SD & $\mathrm{M}$ & SD & M & SD & U Mann-Whitney & $p$ \\
\hline slaps & 2.60 & 1.13 & 2.15 & 1.17 & 2.47 & 1.16 & 970.0 & $<0.05$ \\
\hline kicks & 1.45 & 0.98 & 1.27 & 0.67 & 1.40 & 0.90 & 1214.50 & n.i. \\
\hline pushing/jabbing & 2.27 & 1.30 & 1.66 & 1.08 & 2.09 & 1.26 & 907.5 & $<0.01$ \\
\hline jerking & 2.18 & 1.23 & 1.66 & 0.98 & 2.03 & 1.18 & 975.5 & $<0.05$ \\
\hline pinching & 1.46 & 0.84 & 1.36 & 0.74 & 1.43 & 0.81 & 1233.50 & n.i. \\
\hline scratching & 1.30 & 0.75 & 1.27 & 0.76 & 1.29 & 0.75 & 1296.50 & n.i. \\
\hline biting & 1.24 & 0.64 & 1.09 & 0.29 & 1.19 & 0.56 & 1216.50 & n.i. \\
\hline hair pulling & 1.86 & 1.16 & 1.36 & 0.89 & 1.71 & 1.11 & 942.0 & $<0.01$ \\
\hline hitting & 2.56 & 1.25 & 1.90 & 1.28 & 2.37 & 1.29 & 853.0 & $<0.01$ \\
\hline throwing with a thing & 1.68 & 1.06 & 1.36 & 0.82 & 1.58 & 1.00 & 1069.50 & n.i. \\
\hline beating & 1.86 & 1.06 & 1.21 & 0.64 & 1.66 & 1.04 & 848.0 & $<0.01$ \\
\hline throwing with a person & 1.25 & 0.68 & 1.21 & 0.73 & 1.24 & 0.70 & 1215.50 & n.i. \\
\hline suffocation & 1.17 & 0.52 & 1.00 & 0.00 & 1.12 & 0.44 & 1138.5 & $<0.05$ \\
\hline burning with a cigarette/an iron & 1.11 & 0.45 & 1.15 & 0.71 & 1.12 & 0.53 & 1285.50 & n.i. \\
\hline face slapping & 1.72 & 0.89 & 1.27 & 0.87 & 1.58 & 0.90 & 813.5 & $<0.001$ \\
\hline terrorizing & 1.82 & 1.31 & 1.42 & 1.11 & 1.70 & 1.27 & 1027.5 & $<0.05$ \\
\hline exhaustion & 1.91 & 1.32 & 1.27 & 0.80 & 1.72 & 1.22 & 947.5 & $<0.01$ \\
\hline shouting & 3.74 & 1.25 & 2.87 & 1.19 & 3.49 & 1.29 & 812.0 & $<0.01$ \\
\hline frightening, blackmail & 3.12 & 1.41 & 1.78 & 1.08 & 2.73 & 1.45 & 635.5 & $<0.001$ \\
\hline humiliation, ridiculing & 2.58 & 1.43 & 1.48 & 1.00 & 2.25 & 1.41 & 733.0 & $<0.001$ \\
\hline blaming & 3.06 & 1.37 & 2.00 & 1.06 & 2.75 & 1.37 & 736.0 & $<0.001$ \\
\hline conflicting requirements & 2.94 & 1.28 & 2.12 & 1.13 & 2.70 & 1.29 & 834.0 & $<0.01$ \\
\hline insulting words, curses & 3.12 & 1.39 & 1.87 & 1.02 & 2.75 & 1.40 & 659.0 & $<0.001$ \\
\hline criticizing & 3.58 & 1.16 & 2.63 & 1.16 & 3.30 & 1.23 & 767.0 & $<0.001$ \\
\hline ignoring & 2.93 & 1.45 & 2.15 & 1.09 & 2.70 & 1.39 & 911.0 & $<0.05$ \\
\hline hostility & 2.69 & 1.36 & 1.96 & 1.23 & 2.48 & 1.36 & 899.5 & $<0.01$ \\
\hline
\end{tabular}

Table 3. Differences regarding perpetrator in childhood in the groups $(\mathrm{N}=112)$

\begin{tabular}{|c|c|c|c|c|c|c|c|c|}
\hline \multirow{2}{*}{ Person committing violence } & \multicolumn{2}{|c|}{$\begin{array}{l}\uparrow \text { anxiety } \\
(\mathrm{N}=79)\end{array}$} & \multicolumn{2}{|c|}{$\begin{array}{l}\downarrow \text { anxiety } \\
(\mathrm{N}=33)\end{array}$} & \multicolumn{2}{|c|}{$\begin{array}{l}\text { In general } \\
(\mathrm{N}=112)\end{array}$} & \multicolumn{2}{|c|}{ Significance of differences } \\
\hline & $\mathrm{N}$ & $\%$ & $\mathrm{~N}$ & $\%$ & $\mathrm{~N}$ & $\%$ & $\chi^{2}(\mathrm{df}=5)$ & $p$ \\
\hline mother & 39 & 49.4 & 14 & 42.4 & 53 & 47.3 & 0.450 & n.i \\
\hline father & 46 & 58.2 & 10 & 30.3 & 56 & 50.0 & 7.260 & $<0.01$ \\
\hline siblings & 15 & 19 & 3 & 9.1 & 18 & 16.1 & 1.690 & n.i \\
\hline grandparents & 6 & 7.6 & 0 & 0 & 6 & 5.4 & 2.648 & n.i. \\
\hline teacher & 18 & 22.8 & 4 & 12.1 & 22 & 19.6 & 1.677 & n.i. \\
\hline friend & 26 & 32.9 & 10 & 30.3 & 36 & 32.1 & 0.073 & n.i. \\
\hline other & 18 & 22.8 & 4 & 12.1 & 22 & 19.6 & 1.677 & n.i. \\
\hline
\end{tabular}

Table 4. Feelings experienced in the past during the acts of violence $(\mathrm{N}=112)$

\begin{tabular}{|c|c|c|c|c|c|c|c|c|}
\hline \multirow{2}{*}{$\begin{array}{l}\text { Feelings experienced during the act of } \\
\text { violence }\end{array}$} & \multicolumn{2}{|c|}{$\begin{array}{l}\uparrow \text { anxiety } \\
(\mathrm{N}=79)\end{array}$} & \multicolumn{2}{|c|}{$\begin{array}{l}\downarrow \text { anxiety } \\
(\mathrm{N}=33)\end{array}$} & \multicolumn{2}{|c|}{$\begin{array}{l}\text { In general } \\
(\mathrm{N}=112)\end{array}$} & \multicolumn{2}{|c|}{ Significance of differences } \\
\hline & $\mathrm{N}$ & $\%$ & $\mathrm{~N}$ & $\%$ & $\mathrm{~N}$ & $\%$ & $\chi^{2}(\mathrm{df}=1)$ & $p$ \\
\hline anxiety & 43 & 54.4 & 7 & 21.2 & 50 & 44.6 & 10.393 & $<0.01$ \\
\hline powerlessness & 36 & 46.2 & 7 & 21.2 & 43 & 38.7 & 6.079 & $<0.05$ \\
\hline anger & 36 & 45.6 & 19 & 57.6 & 55 & 49.1 & 1.343 & n.i. \\
\hline humiliation & 27 & 34.2 & 9 & 27.3 & 36 & 32.1 & 0.509 & n.i. \\
\hline other & 6 & 7.6 & 3 & 9.1 & 9 & 8 & 0.070 & n.i. \\
\hline
\end{tabular}


Table 5 Kinds of feelings currently experienced during recalling trauma of violence $(N=112)$

\begin{tabular}{|c|c|c|c|c|c|c|c|c|}
\hline \multirow{2}{*}{ Current feelings towards violence } & \multicolumn{2}{|c|}{$\begin{array}{l}\uparrow \text { anxiety } \\
(\mathrm{N}=79)\end{array}$} & \multicolumn{2}{|c|}{$\begin{array}{l}\downarrow \text { anxiety } \\
(\mathrm{N}=33)\end{array}$} & \multicolumn{2}{|c|}{$\begin{array}{l}\text { In general } \\
(\mathrm{N}=112)\end{array}$} & \multicolumn{2}{|c|}{ Significance of differences } \\
\hline & $\mathrm{N}$ & $\%$ & $\mathrm{~N}$ & $\%$ & $\mathrm{~N}$ & $\%$ & $\begin{array}{l}\chi^{2} \\
(\mathrm{df}=1)\end{array}$ & $p$ \\
\hline fear & 7 & 8.9 & 0 & 0 & 7 & 6.3 & 3.119 & n.i. \\
\hline powerlessness & 16 & 20.3 & 1 & 3 & 17 & 15.2 & 5.363 & $<0.05$ \\
\hline anger & 33 & 41.8 & 12 & 36.4 & 45 & 40.2 & 0.283 & n.i. \\
\hline humiliation & 23 & 29.1 & 7 & 21.2 & 30 & 26.8 & 0.741 & n.i. \\
\hline other & 20 & 25.3 & 17 & 51.5 & 37 & 33 & 7.222 & $<0.01$ \\
\hline
\end{tabular}

In the studied group more than twice more often people pointed to the feeling of anxiety (understood as temporary emotional state) $(\mathrm{p}=0.001)$ and sense of powerlessness ( $p=0.014)$, (Tab. 4.).

When examined people recalls their past after years, they declared persistent sense of powerlessness. This feeling was present in respondents from the group with high level of anxiety as a trait nearly seven times more often ( $p=0.021)$. People with low level of anxiety as a trait significantly more often $(p=0.007)$ reported presence of other emotions (verbalized as "indifference", "I feel nothing", "it's all water over the dam", "now it's me who can beat", etc.; Tab.5.).

\section{Comparison between groups regarding current con- tact with violence}

The most of respondents (63.4\%) have still been in contact with person who was aggressor in the past (67.1\% people with high level of anxiety as a trait and $54.5 \%$ people with low level of it). Moreover, it was revealed that a quarter of them $(26.8 \%)$ have been living with them under one roof - (accordingly, 32.9\% of the first group and $12.1 \%$ of the second one). Significantly more often it is true for persons with high level of anxiety as a trait $\left(\chi^{2}=5.130 ; \mathrm{df}=1 ; p=0.024\right)$. Every fifth person in the whole group (18.8\%) is currently victim of domestic violence and persons from the group with high level of anxiety as a state $(24.1 \%)$ are four times more often present in this subgroup in comparison with the second group $(6.1 \%)\left(\chi^{2}=4.945 ; \mathrm{df}=1 ; p=0.026\right)$. One third of the whole group commits violence towards other people and persons with high level of anxiety as a state do it twice more often $(36.7 \%)$ than people with low level of it $(15.2 \%)\left(\chi^{2}=5.117 ; \mathrm{df}=1 ; p=0.024\right)$. Detailed results are presented in Table 6.

\section{Discussion}

This study was aimed to looking for correlations between experiencing of domestic violence in childhood and identified level of anxiety understood in the C.D.Spielberger et al. from the point of view as fixed trait of personality [10]. In order to do that, we were looking for differences between results of respondents divided by severity of personality trait of anxiety, in the form of Polish adaptation of the State-Trait Anxiety Inventory by C.D.Spielberger . The results showed high percentage of people committing domestic violence, despite the fact that they experienced it during childhood and its consequences later in the future. It can be suspected that in part of them, these experiences consolidate as personality trait of anxiety. At the same time, the studied persons admitted that they have been in contact with aggressor, despite of harmful experiences. Looking for sense of co-existing mechanisms of appearing both anxiety and aggression this phenomenon can be explained by, for example, the theory of attribution. According to it, in situation of contact with an impulse causing anxiety - observed aggressive behaviour may play role of defence mechanisms [11]. We can look for clarification of causes of the presented behavioural patterns (of both emotional reactions and observed aggressive behaviours) in the A.Bandura and R.H.Walter's theory of social learning [12]. Aggressiveness in young person is explained by complex process of learning behaviours by observing and imitation. As it was broadly documented, aggression is mostly learned behaviour and observation of aggressive behaviours has proven sustained influence on children[13]. Mechanism of social learning consists of fact that a child identifies with observed behavioural model and it can be suspected that intensity of identification directly influences modelled person. The bigger closeness of emotional bond with a model of behaviour, the stronger process of identification. In this study, more than half of respondents has still been in touch with the aggressor, has been living together or has created partner relationship based on the similar schemes of interpersonal relations. These persons are under a great influence of past experiences, they are not able to break known pattern of creating and developing relationships. Moreover, it can be suspected that, apart from social learning, the phenomenon of displace aggression takes place here. In our study near a half of people experiencing violence in childhood, are currently aggressors towards other people. This phenomenon means addressing reciprocal aggression towards a person or 
object different from that one which a person would like to revenge [14]. In the time point of view, therapeutic work with victims of domestic violence creates possibility to counteract the phenomenon of learned helplessness and copying destructive family patterns. Also awareness of psychological consequences of using violence towards the youngest permits to hope to optimisation of actions preventing spreading of such pathology.

\section{Conclusions}

1. People with high level of anxiety as a trait significantly more often experienced violence in childhood (physical and mental) than people with low level of it.
2. Violence experienced during childhood has more often mental nature than physical one.

3. High level of anxiety as a trait was significantly more often correlated with using violence by father $(\mathrm{p}<0.01)$.

4. Feelings of fear and helplessness dominating in the time of experiencing violence significantly more often concern people with high level of anxiety as a trait and with time consolidate as persistently present sense of helplessness $(p<0.05)$.

5. People with high level of anxiety as a trait significantly more often have still been experiencing violence, have lived with perpetrators and have used violence toward other people $(\mathrm{p}<0.05)$.

\section{WPROWADZENIE TEORETYCZNE}

Problematyka przemocy domowej od dawna stanowi przedmiot zainteresowania teoretyków i badaczy, porusza opinię publiczną oraz media. Wg statystyk ostatnich lat w Polsce przemoc domowa dotyka ponad 113,5 tys. osób, z czego blisko $20 \%$ stanowią dzieci do lat 13 [1]. Co roku na skutek różnych form krzywdzenia dzieci, aż kilkadziesięcioro z nich umiera [2]. Statystyki medyczne rejestrują zaledwie nieliczne, zwykle skrajne przypadki maltretowania dzieci, a zespół obrażeń fizycznych i psychicznych powstałych na skutek stosowania przemocy nazywa się „syndromem dziecka krzywdzonego” [2, 3]. Wiele aktów agresji wobec najmłodszych ma miejsce w zaciszu domów i pozostaje nigdzie niezgłoszonych.

Z psychologicznego punktu widzenia emocjonalne skutki życia blisko agresora można rozpatrywać w kategoriach doświadczanego dystresu. W okresie dzieciństwa ma miejsce kształtowanie zasadniczych zrębów struktury psychicznej i osobowości człowieka [4-6]. Frustracja podstawowej potrzeby bezpieczeństwa, z rąk osób, które w tym czasie w naturalny sposób predysponowane są do zapewnienia małoletnim ochrony (czyli rodziców i opiekunów), ma szczególnie destrukcyjny wpływ na aktualne i późniejsze biopsychospołeczne funkcjonowanie dzieci. Udokumentowane są przypadki osób małoletnich, które będąc świadkami lub ofiarami przemocy ponoszą psychologiczne koszta, w postaci utrzymującego się lęku, wyuczonej bezradności, utrwalonej postawy wrogości, niskiej samooceny, problemów z kontrolą emocji, trudności w relacjach interpersonalnych oraz myśli o charakterze intruzywnym [7-9]. Wśród małoletnich ofiar przemocy domowej częściej odnotowuje się objawy somatyczne i depresyjne, co więcej - reakcje rezygnacyjne oraz próby samobójcze [7]. Te ostatnie, traktowane jako formy acting out-ów (emocji rozegranych w zachowaniu), są wyrazem niewłaściwej regulacji emocji, nieradzenia sobie ze stresem oraz potrzeby wsparcia społecznego.

\section{CEL}

Celem pracy było poszukiwanie zależności pomiędzy doświadczaniem różnych form krzywdzenia w dzieciństwie a nasileniem osobowościowej cechy lęku u ofiar przemocy domowej. Porównywano osoby $\mathrm{z}$ wysokim i niskim poziomem lęku jako cechy w zakresie: doznawanych form przemocy, sprawców (źródeł) przemocy, emocji pojawiających się $\mathrm{w}$ reakcji na doświadczaną przemoc oraz aktualnej sytuacji życiowej (tj. obecnego kontaktu $\mathrm{z}$ agresorem i stosowania przemocy).

\section{MATERIAL I METODY Osoby badane}

Metody badawcze rozdano 147 osobom korzystającym z Poradni Zdrowia Psychicznego na terenie województwa mazowieckiego ${ }^{2}$. Kryterium zakwalifikowania do badań stanowiła przemoc w dzieciństwie w wywiadzie oraz brak znaczących zaburzeń psychicznych (tj. brak historii leczenia psychiatrycznego). Udział $\mathrm{w}$ badaniach był dobrowolny, anonimowy, $\mathrm{z}$ zachowaniem kodeksu etyki zawodu psychologa. Spośród takiej grupy respondentów metodą kwartyli wyłoniono grupy skrajne, tj. z najwyższymi (grupa badana, $\mathrm{N}=79$ ) i najniższymi wynikami (grupa kontrolna, $\mathrm{N}=33$ ) w zakresie poziomu lęku jako cechy. Dalszym analizom statystycznym poddano ostatecznie 112 osób (49 kobiet i 63 mężczyzn), wiek badanych obejmował przedział między 18 a 59 rokiem życia (średnia wieku wynosiła ogółem 36 lat). Szczegółową charakterystykę socjodemograficzną badanej grupy osób przedstawiono w Tabeli 1.

Grupę badaną tworzyły w większości osoby stanu wolnego (46,8\%), pochodzące z miejscowości powyżej 100 tys. mieszkańców $(48,1 \%)$, dominowało wykształcenie średnie $(35,4 \%)$ i zawodowe $(27,8 \%)$ oraz niekorzystnie oceniana sytuacja materialna $(29,5 \%)$. Osoby z grupy kontrolnej w większości posiadały partnerów $(36,4 \%)$ i własne

\footnotetext{
${ }^{2}$ Badania przeprowadzała p. Jolanta Burdelas.
} 
Tabela 1 Charakterystyka socjodemograficzna badanych osób (N=112)

\begin{tabular}{|c|c|c|c|c|c|c|c|c|c|}
\hline & \multicolumn{2}{|c|}{$\begin{array}{c}\uparrow \text { lęk } \\
(\mathrm{N}=79)\end{array}$} & \multicolumn{2}{|c|}{$\begin{array}{c}\downarrow \text { lęk } \\
(\mathrm{N}=33)\end{array}$} & \multicolumn{2}{|c|}{$\begin{array}{l}\text { ogółem } \\
\text { (N=112) }\end{array}$} & \multicolumn{2}{|c|}{ istotność różnic } \\
\hline & & $\mathrm{N}$ & $\%$ & $\mathrm{~N}$ & $\%$ & $\mathrm{~N}$ & $\%$ & $t(d f=1)$ & $\mathrm{p}$ \\
\hline \multirow{2}{*}{ płeć } & kobiety & 32 & 40,5 & 17 & 51,5 & 49 & 43,8 & \multirow{2}{*}{1,146} & \multirow{2}{*}{ n.i. } \\
\hline & mężczyźni & 47 & 59,5 & 16 & 48,5 & 63 & 56,3 & & \\
\hline \multirow{2}{*}{\multicolumn{2}{|c|}{ wiek }} & $\mathrm{M}$ & SD & $\mathrm{M}$ & SD & $\mathrm{M}$ & SD & $\mathrm{t}(\mathrm{df}=110)$ & $\mathrm{p}$ \\
\hline & & 35,18 & 10,73 & 35,72 & 10,32 & 36,34 & 10,57 & 0,244 & n.i. \\
\hline \multicolumn{2}{|c|}{ wykształcenie } & $\mathrm{N}$ & $\%$ & $\mathrm{~N}$ & $\%$ & $\mathrm{~N}$ & $\%$ & $\chi^{2}(\mathrm{df}=4)$ & $\mathrm{p}$ \\
\hline \multicolumn{2}{|c|}{ podstawowe } & 14 & 17,7 & 4 & 12,1 & 18 & 16,1 & \multirow{5}{*}{4,015} & \multirow{5}{*}{ n.i. } \\
\hline \multicolumn{2}{|c|}{ zawodowe } & 22 & 27,8 & 7 & 21,2 & 29 & 25,9 & & \\
\hline \multicolumn{2}{|c|}{ średnie } & 28 & 35,4 & 13 & 39,4 & 41 & 36,6 & & \\
\hline \multicolumn{2}{|c|}{ wyższe } & 12 & 15,2 & 9 & 27,3 & 21 & 18,8 & & \\
\hline \multicolumn{2}{|l|}{ inne } & 3 & 3,8 & 0 & 0 & 3 & 2,7 & & \\
\hline \multicolumn{2}{|c|}{ zamieszkanie } & $\mathrm{N}$ & $\%$ & $\mathrm{~N}$ & $\%$ & $\mathrm{~N}$ & $\%$ & $\chi^{2}(\mathrm{df}=3)$ & $\mathrm{p}$ \\
\hline \multicolumn{2}{|l|}{ wieś } & 19 & 24,1 & 10 & 31,1 & 29 & 26,1 & \multirow{4}{*}{3,829} & \multirow{4}{*}{ n.i. } \\
\hline \multicolumn{2}{|c|}{$\begin{array}{l}\text { miasto do } 50 \text { tys. mieszkań- } \\
\text { ców }\end{array}$} & 18 & 22,8 & 11 & 34,4 & 29 & 26,1 & & \\
\hline \multicolumn{2}{|c|}{$\begin{array}{l}\text { miasto 50-100 tys. miesz- } \\
\text { kańców }\end{array}$} & 4 & 5,1 & 2 & 6,3 & 6 & 5,4 & & \\
\hline $\begin{array}{l}\text { mias } \\
\text { kańc }\end{array}$ & w. 100 tys. miesz- & 38 & 48,1 & 9 & 28,1 & 47 & 42,3 & & \\
\hline stan & & $\mathrm{N}$ & $\%$ & $\mathrm{~N}$ & $\%$ & $\mathrm{~N}$ & $\%$ & $\chi^{2}(\mathrm{df}=5)$ & $\mathrm{p}$ \\
\hline zamę & zonaty & 22 & 27,8 & 12 & 36,4 & 34 & 30,4 & & \\
\hline osob & viedziona & 10 & 12,7 & 1 & 3 & 11 & 9,8 & & \\
\hline separ & & 4 & 5,1 & 4 & 12,1 & 8 & 7,1 & 4552 & $n j$ \\
\hline pann & waler & 37 & 46,8 & 14 & 42,4 & 51 & 45,5 & 4,JJL & 11.1. \\
\hline w wo & związku & 3 & 3,8 & 1 & 3 & 4 & 3,6 & & \\
\hline inny & & 3 & 3,8 & 1 & 3 & 4 & 3,6 & & \\
\hline statu & odowy & $\mathrm{N}$ & $\%$ & $\mathrm{~N}$ & $\%$ & $\mathrm{~N}$ & $\%$ & $\chi^{2}(\mathrm{df}=4)$ & $\mathrm{p}$ \\
\hline uczer & dent & 5 & 6,3 & 8 & 24,2 & 13 & 11,6 & & \\
\hline pracc & umysłowy & 19 & 24,1 & 13 & 39,4 & 32 & 28,6 & & \\
\hline prace & fizyczny & 24 & 30,4 & 8 & 24,2 & 32 & 28,6 & 15,604 & $<0.01$ \\
\hline bezrc & & 17 & 21,5 & 4 & 12,1 & 21 & 18,8 & & \\
\hline inny & & 14 & 17,7 & 0 & 0 & 14 & 12,5 & & \\
\hline zami & & $\mathrm{N}$ & $\%$ & $\mathrm{~N}$ & $\%$ & $\mathrm{~N}$ & $\%$ & $\chi^{2}(\mathrm{df}=2)$ & $\mathrm{p}$ \\
\hline z załc & rodziną & 27 & 34,6 & 19 & 57,6 & 46 & 41,4 & & \\
\hline samo & & 25 & 32,1 & 8 & 24,2 & 33 & 29,7 & 5,272 & n.i. \\
\hline inne & & 26 & 22,5 & 6 & 18,2 & 32 & 28,8 & & \\
\hline dries & & $\mathrm{M}$ & SD & $\mathrm{M}$ & SD & $\mathrm{M}$ & SD & $\mathrm{t}(\mathrm{df}=110)$ & $\mathrm{p}$ \\
\hline azlec & & 1,11 & 1,56 & 1,45 & 1,22 & 1,21 & 1,47 & 1,117 & n.i. \\
\hline sytua & aterialna & $\mathrm{N}$ & $\%$ & $\mathrm{~N}$ & $\%$ & $\mathrm{~N}$ & $\%$ & $\chi^{2}(\mathrm{df}=5)$ & $\mathrm{p}$ \\
\hline bard & & 2 & 2,6 & 1 & 3 & 3 & 2,7 & & \\
\hline dobr & & 15 & 19,2 & 10 & 30,3 & 25 & 22,5 & & \\
\hline racze & & 24 & 30,8 & 15 & 45,5 & 39 & 35,1 & 6886 & $n i$ \\
\hline racze & & 23 & 29,5 & 5 & 15,2 & 28 & 25,2 & 0,000 & 11.1. \\
\hline zła & & 8 & 10,3 & 1 & 3 & 9 & 8,1 & & \\
\hline bard & & 6 & 7,7 & 1 & 3 & 7 & 6,3 & & \\
\hline
\end{tabular}

rodziny $(57,6 \%)$, wykształcenie średnie $(39,4 \%)$ i wyższe $(27,3 \%)$, zamieszkiwały $\mathrm{z}$ reguły małe miejscowości $(34,4 \%)$, a sytuację materialną oceniały jako dobrą $(45,5 \%)$. W zakresie kontrolowanych zmiennych socjodemograficznych grupy nie różniły się istotnie statystycznie. Jedyna znacząca różnica dotyczyła statusu zawodowego. W grupie badanej znacznie więcej osób nie posiadało pracy $(21,5 \%)$ lub przebywało na rencie $(17,7 \%)$, podczas gdy grupę kontrolną w większości tworzyły osoby pracujące $(63,6 \%)$ bądź podnoszące kwalifikacje zawodowe $(24,2 \%)\left(\chi^{2}=15,604 ; \mathrm{df}=4 ; p=0,004\right)$.

\section{Zastosowane narzędzia badawcze}

W badaniach zastosowano ankietę osobową oraz kwestionariusz STAI (State-Trait Anxiety Inventory) C.D. Spielbergera, R.L. Gorsucha i R.E. Lushene'a, w polskiej adaptacji J. Strelau'a, M. Tysarczyka i K. Wrześniewskiego (Inwentarz Stanu i Cechy Lęku, ISCL).

Ankieta składała się z 17 pytań. Dla potrzeb niniejszego opracowania poza częścią zbierającą dane socjodemograficzne (9 itemów) pytano o formy doznawanej przemocy, źródła przemocy, reakcje emocjonalne ofiar w kontekście doświadczanej przemocy, a także obecną aktualnie sytuację (kontakt z agresorem oraz stosowanie przemocy). 
Tabela 2 Różnice dotyczące form doznawanej przemocy w dzieciństwie w badanych grupach osób (N=112)

\begin{tabular}{|c|c|c|c|c|c|c|c|c|}
\hline \multirow{2}{*}{ formy przemocy } & \multicolumn{2}{|l|}{$\begin{array}{l}\uparrow \text { lęk } \\
(\mathrm{N}=79)\end{array}$} & \multicolumn{2}{|c|}{$\begin{array}{l}\downarrow \text { lęk } \\
(\mathrm{N}=33)\end{array}$} & \multicolumn{2}{|c|}{$\begin{array}{l}\text { ogółem } \\
(\mathrm{N}=112)\end{array}$} & \multicolumn{2}{|c|}{ isto tność różnic } \\
\hline & M & SD & M & SD & M & SD & $\begin{array}{l}\text { U Manna- } \\
\text { Whitneya }\end{array}$ & $p$ \\
\hline klapsy & 2,60 & 1,13 & 2,15 & 1,17 & 2,47 & 1,16 & 970,0 & $<0.05$ \\
\hline kopanie & 1,45 & 0,98 & 1,27 & 0,67 & 1,40 & 0,90 & 1214,50 & n.i. \\
\hline popychanie/szturchanie & 2,27 & 1,30 & 1,66 & 1,08 & 2,09 & 1,26 & 907,5 & $<0.01$ \\
\hline szarpanie & 2,18 & 1,23 & 1,66 & 0,98 & 2,03 & 1,18 & 975,5 & $<0.05$ \\
\hline szczypanie & 1,46 & 0,84 & 1,36 & 0,74 & 1,43 & 0,81 & 1233,50 & n.i. \\
\hline drapanie & 1,30 & 0,75 & 1,27 & 0,76 & 1,29 & 0,75 & 1296,50 & n.i. \\
\hline gryzienie & 1,24 & 0,64 & 1,09 & 0,29 & 1,19 & 0,56 & 1216,50 & n.i. \\
\hline ciągnięcie za włosy & 1,86 & 1,16 & 1,36 & 0,89 & 1,71 & 1,11 & 942,0 & $<0.01$ \\
\hline uderzanie & 2,56 & 1,25 & 1,90 & 1,28 & 2,37 & 1,29 & 853,0 & $<0.01$ \\
\hline rzucanie przedmiotem & 1,68 & 1,06 & 1,36 & 0,82 & 1,58 & 1,00 & 1069,50 & n.i. \\
\hline pobicie & 1,86 & 1,06 & 1,21 & 0,64 & 1,66 & 1,04 & 848,0 & $<0.01$ \\
\hline rzucanie kimś & 1,25 & 0,68 & 1,21 & 0,73 & 1,24 & 0,70 & 1215,50 & n.i. \\
\hline duszenie & 1,17 & 0,52 & 1,00 & 0,00 & 1,12 & 0,44 & 1138,5 & $<0.05$ \\
\hline przypalanie papierosem/żelazkiem & 1,11 & 0,45 & 1,15 & 0,71 & 1,12 & 0,53 & 1285,50 & n.i. \\
\hline policzkowanie & 1,72 & 0,89 & 1,27 & 0,87 & 1,58 & 0,90 & 813,5 & $<0.001$ \\
\hline terroryzowanie & 1,82 & 1,31 & 1,42 & 1,11 & 1,70 & 1,27 & 1027,5 & $<0.05$ \\
\hline obezwładnianie & 1,91 & 1,32 & 1,27 & 0,80 & 1,72 & 1,22 & 947,5 & $<0.01$ \\
\hline krzyczenie & 3,74 & 1,25 & 2,87 & 1,19 & 3,49 & 1,29 & 812,0 & $<0.01$ \\
\hline straszenie, grożenie, szantaż & 3,12 & 1,41 & 1,78 & 1,08 & 2,73 & 1,45 & 635,5 & $<0.001$ \\
\hline upokarzanie, ośmieszanie & 2,58 & 1,43 & 1,48 & 1,00 & 2,25 & 1,41 & 733,0 & $<0.001$ \\
\hline obwinianie & 3,06 & 1,37 & 2,00 & 1,06 & 2,75 & 1,37 & 736,0 & $<0.001$ \\
\hline sprzeczne wymagania & 2,94 & 1,28 & 2,12 & 1,13 & 2,70 & 1,29 & 834,0 & $<0.01$ \\
\hline obraźliwe słowa/ przekleństwa & 3,12 & 1,39 & 1,87 & 1,02 & 2,75 & 1,40 & 659,0 & $<0.001$ \\
\hline krytykowanie & 3,58 & 1,16 & 2,63 & 1,16 & 3,30 & 1,23 & 767,0 & $<0.001$ \\
\hline ignorowanie & 2,93 & 1,45 & 2,15 & 1,09 & 2,70 & 1,39 & 911,0 & $<0.05$ \\
\hline wrogość & 2,69 & 1,36 & 1,96 & 1,23 & 2,48 & 1,36 & 899,5 & $<0.01$ \\
\hline
\end{tabular}

Tabela 3 Różnice dotyczące osoby stosującej przemoc w dzieciństwie w badanych grupach (N=112)

\begin{tabular}{|c|c|c|c|c|c|c|c|c|}
\hline \multirow[b]{2}{*}{ osoba stosująca przemoc } & \multicolumn{2}{|c|}{$\begin{array}{l}\uparrow \text { lęk } \\
(\mathrm{N}=79)\end{array}$} & \multicolumn{2}{|c|}{$\begin{array}{l}\downarrow \text { lęk } \\
(\mathrm{N}=33)\end{array}$} & \multicolumn{2}{|c|}{$\begin{array}{l}\text { ogółem } \\
(\mathrm{N}=112)\end{array}$} & \multicolumn{2}{|c|}{ istotność różnic } \\
\hline & $\mathrm{N}$ & $\%$ & $\mathrm{~N}$ & $\%$ & $\mathrm{~N}$ & $\%$ & $\begin{array}{l}\chi^{2} \\
(\mathrm{df}=5)\end{array}$ & $p$ \\
\hline matka & 39 & 49,4 & 14 & 42,4 & 53 & 47,3 & 0,450 & n.i. \\
\hline ojciec & 46 & 58,2 & 10 & 30,3 & 56 & 50,0 & 7,260 & $<0.01$ \\
\hline rodzeństwo & 15 & 19 & 3 & 9,1 & 18 & 16,1 & 1,690 & n.i. \\
\hline babcia i dziadek & 6 & 7,6 & 0 & 0 & 6 & 5,4 & 2,648 & n.i. \\
\hline nauczyciel & 18 & 22,8 & 4 & 12,1 & 22 & 19,6 & 1,677 & n.i. \\
\hline kolega & 26 & 32,9 & 10 & 30,3 & 36 & 32,1 & 0,073 & n.i. \\
\hline ktoś inny & 18 & 22,8 & 4 & 12,1 & 22 & 19,6 & 1,677 & n.i. \\
\hline
\end{tabular}

Tabela 4 Rodzaje uczuć doznawanych w przeszłości podczas aktu przemocy (N=112)

\begin{tabular}{|c|c|c|c|c|c|c|c|c|}
\hline \multirow{2}{*}{ uczucia doznawane podczas przemocy } & \multicolumn{2}{|c|}{$\begin{array}{l}\uparrow \text { lęk } \\
(\mathrm{N}=79)\end{array}$} & \multicolumn{2}{|c|}{$\begin{array}{l}\downarrow \text { lęk } \\
(\mathrm{N}=33)\end{array}$} & \multicolumn{2}{|c|}{$\begin{array}{l}\text { ogółem } \\
(\mathrm{N}=112)\end{array}$} & \multicolumn{2}{|c|}{ istotność różnic } \\
\hline & $\mathrm{N}$ & $\%$ & $\mathrm{~N}$ & $\%$ & $\mathrm{~N}$ & $\%$ & $\begin{array}{l}\chi^{2} \\
(\mathrm{df}=1)\end{array}$ & $p$ \\
\hline lęk & 43 & 54,4 & 7 & 21,2 & 50 & 44,6 & 10,393 & $<0.01$ \\
\hline bezsilność & 36 & 46,2 & 7 & 21,2 & 43 & 38,7 & 6,079 & $<0.05$ \\
\hline złość & 36 & 45,6 & 19 & 57,6 & 55 & 49,1 & 1,343 & n.i. \\
\hline upokorzenie & 27 & 34,2 & 9 & 27,3 & 36 & 32,1 & 0,509 & n.i. \\
\hline inne & 6 & 7,6 & 3 & 9,1 & 9 & 8 & 0,070 & n.i. \\
\hline
\end{tabular}

Tabela 5 Rodzaje uczuć doznawanych obecnie w momencie wspomnienia doświadczonej przemocy (N=112)

\begin{tabular}{|c|c|c|c|c|c|c|c|c|}
\hline \multirow{2}{*}{$\begin{array}{l}\text { aktualne odczucia } \\
\text { wobec przemocy }\end{array}$} & \multicolumn{2}{|c|}{$\begin{array}{l}\uparrow \text { lęk } \\
(\mathrm{N}=79)\end{array}$} & \multicolumn{2}{|c|}{$\begin{array}{l}\downarrow \text { lęk } \\
(\mathrm{N}=33)\end{array}$} & \multicolumn{2}{|c|}{$\begin{array}{l}\text { ogółem } \\
(\mathrm{N}=112)\end{array}$} & \multicolumn{2}{|c|}{ istotność różnic } \\
\hline & $\mathrm{N}$ & $\%$ & $\mathrm{~N}$ & $\%$ & $\mathrm{~N}$ & $\%$ & $\begin{array}{l}\chi^{2} \\
(\mathrm{df}=1)\end{array}$ & $p$ \\
\hline lęk & 7 & 8,9 & 0 & 0 & 7 & 6,3 & 3,119 & n.i. \\
\hline bezsilność & 16 & 20,3 & 1 & 3 & 17 & 15,2 & 5,363 & $<0.05$ \\
\hline złość & 33 & 41,8 & 12 & 36,4 & 45 & 40,2 & 0,283 & n.i. \\
\hline upokorzenie & 23 & 29,1 & 7 & 21,2 & 30 & 26,8 & 0,741 & n.i. \\
\hline inne & 20 & 25,3 & 17 & 51,5 & 37 & 33 & 7,222 & $<0.01$ \\
\hline
\end{tabular}


Polska wersja kwestionariusza STAI składa się z dwóch części, po 20 pytań każda. Część pierwsza dotyczy oceny lęku rozumianego jako stan (emocja odczuwalna w danym momencie), natomiast druga - lęku rozumianego jako cecha (predyspozycja osobowościowa, odczuwalna zazwyczaj). Pierwsza część metody bada występowanie lęku, druga - jego częstotliwość. Zgodność wewnętrzna (współczynnik $\alpha$ Cronbacha) i stabilność bezwzględna kwestionariusza jest wysoka (wskaźnik rzetelności przekracza 0,80) [10].

\section{Metody analizy statystycznej}

Wyniki badań poddano analizie statystycznej za pomocą pakietu statystycznego SPSS for Windows 14.0 PL. Opracowując dane zastosowano metody opisowe oraz metody wnioskowania statystycznego. Porównanie średnich wyników w badanych grupach osób poprzedzono sprawdzeniem zgodności rozkładów analizowanych cech mierzalnych z rozkładem normalnym za pomocą testu $\lambda$-Kołmogorowa. Istotności różnic pomiędzy grupami badano odpowiednio testem $\mathrm{t}$ Studenta, testem $\chi^{2}$ oraz testem U Manna-Whitneya. Za poziom granicy istotności różnic przyjęto $\mathrm{p}<0.05$.

\section{WYNIKI}

\section{Porównanie doświadczanych form przemocy u osób z wysokim i niskim poziomem cechy lęku}

Badania ujawniły, że osoby charakteryzujące się wysokim poziomem cechy lęku w porównaniu z osobami z niskim poziomem cechy lęku różnią się znacząco statystycznie pod względem doświadczanych form przemocy domowej. Po pierwsze, osoby z grupy badanej wskazywały na znacząco częstsze (skala przedziałowa) doznawanie zarówno przemocy fizycznej, jak i psychicznej aniżeli osoby z grupy kontrolnej. Po drugie, w grupie badawczej osoby częściej wskazywały na dotykające ich w dzieciństwie różne formy przemocy psychicznej, a rzadziej fizycznej $(p<0,001$, por. Tabela 2$)$.

\section{Porównanie grup w zakresie sprawców (źródet) przemocy}

Badania ujawniły, że osoby z wysokim poziomem cechy lęku blisko dwukrotnie liczniej wskazywały na ojca jako sprawcę przemocy $(58,2 \%)$ niż osoby z niską cechą lęku $(30,3 \%)$ ( $p=0.007)$. Mimo, że różnice między badanymi grupami dotyczące pozostałych osób stosujących przemoc okazały się nieistotne statystycznie, to zauważalne jest, że osoby z nasiloną cechą lęku około dwukrotnie częściej doznawały przemocy także od rodzeństwa, nauczycieli oraz innych osób („ojczym”, „wychowawca”, „opiekun z domu dziecka”), aniżeli badani z niską cechą lęku. U części respondentów (7,6\%) z grupy badanej sprawcami przemocy domowej byli dziadkowie (takich odpowiedzi nie zanotowano natomiast w grupie kontrolnej, por. Tabela 3).

\section{Porównanie grup w zakresie emocji występujących w reakcji na doświadczana przemoc}

Istotną częścią projektu badawczego była analiza wyników w zakresie pojawiających się uczuć doznawanych $\mathrm{w}$ przeszłości podczas aktu przemocy, ale także aktualnie, na wspomnienie tych zdarzeń. W grupie badanej ponad dwukrotnie więcej osób wskazywało na doświadczanie podczas aktu przemocy w dzieciństwie uczucia lęku (rozumianego jako chwilowy stan emocjonalny) ( $\mathrm{p}=0.001$ ) oraz uczucia bezsilności ( $\mathrm{p}=0.014$ ) (por. Tabela 4).

Po latach wspominając doświadczaną przemoc badane osoby deklarowały utrzymujące się uczucie bezsilności, przy czym blisko siedmiokrotnie więcej osób, których to dotyczyło charakteryzował wysoki poziom cechy lęku $(\mathrm{p}=0.021)$. Osoby z niską cechą lęku znacząco liczniej ( $\mathrm{p}=0.007)$ wskazywały natomiast na obecność innego typu odczuć (werbalizowanych jako „obojętność”, ,nic nie czuję”, , „było minęło”, „teraz to ja mogę przylać”itp.) (por. Tabela 5).

\section{Porównanie grup w zakresie aktualnego kontaktu z przemoca}

Większość respondentów $(63,4 \%)$ w dalszym ciągu utrzymuje kontakt z osobą, od której doznawali niegdyś przemocy $(67,1 \%$ osób z wysokim i $54,5 \%$ z niskim poziomem cechy lęku). Co więcej, badania wykazały, że jedna czwarta $(26,8 \%)$ nadal mieszka $\mathrm{z}$ agresorem (odpowiednio $32,9 \%$ dla pierwszej i $12,1 \%$ dla drugiej grupy). Przy czym znacząco liczniej zamieszkiwanie z agresorem dotyczy osób z wysoką cechą lęku $\left(\chi^{2}=5,130\right.$; $\mathrm{df}=1$; $p=0,024)$. Co piąta spośród wszystkich badanych osób $(18,8 \%)$ obecnie także pada ofiarą przemocy domowej, przy czym czterokrotnie więcej w tej grupie znajduje się osób z wysoką $(24,1 \%)$ niż z niską $(6,1 \%)$ cechą lęku $\left(\chi^{2}=4,945 ; d f=1 ; p=0,026\right)$. Jedna trzecia ze wszystkich badanych stosuje przemoc wobec innych, przy czym osoby $\mathrm{z}$ wysoką cechą lęku robią to przeszło dwukrotnie liczniej $(36,7 \%)$ niż osoby z niską cechą lęku $(15,2 \%)$ $\left(\chi^{2}=5,117 ; \mathrm{df}=1 ; p=0,024\right)$. Szczegółowe wyniki przedstawiono w Tabeli 6 .

\section{DYSKUSJA}

Realizowany projekt badawczy miał na celu poszukiwanie związków pomiędzy doświadczeniem przemocy domowej w dzieciństwie a identyfikowanym poziomem lęku, rozumianym w ujęciu C.D. Spielbergera i wsp. jako utrwalona osobowościowo cecha [10]. Cel ten starano się osiągnąć na drodze poszukiwania różnic pomiędzy wynikami respondentów podzielonych z uwagi na nasilenie cechy lęku, której poziom określano z wykorzystaniem polskiej adaptacji kwestionariusza C.D. Spielbergera State-Trait Anxiety Inventory (STAI). Przeprowadzone badania ujawniły wysoki odsetek osób stosujących przemoc domową, pomimo doświadczania jej we własnym dzieciństwie i ponoszenia konsekwencji tych zdarzeń 
w przyszłości. Można podejrzewać, że u części z nich doświadczenia te utrwalają się w postaci osobowościowej cechy lęku. Jednocześnie badane osoby przyznawały się do podtrzymywania kontaktu $\mathrm{z}$ agresorami, pomimo doświadczenia krzywdy. Poszukując sensu współwystępujących tu mechanizmów pojawiania się zarówno lęku, jak i agresji, zjawisko to wyjaśniać można m.in. w oparciu o teorię atrybucji. Zgodnie z nią, w sytuacji kontaktu z bodźcem lękotwórczym, obserwowalne zachowania agresywne mogą pełnić funkcję zachowań obronnych [11]. Wyjaśnienia przyczyn identyfikowanych w prezentowanych badaniach wzorców tak emocjonalnego reagowania, jak i obserwowalnego agresywnego zachowania można także poszukiwać w oparciu o teorię społecznego uczenia się A. Bandury i R. H. Waltera [12], w myśl której agresywność wyjaśnia się przez złożony proces uczenia się nabywania zachowań poprzez trwającą w czasie obserwację oraz naśladownictwo. Jak to zostało już wielokrotnie udokumentowane, agresja jest w znacznym stopniu zachowaniem wyuczonym, a obserwowanie zachowań agresywnych ma dowiedziony, długotrwały wpływ na dzieci [13]. Mechanizm uczenia się społecznego polega na tym, że dziecko identyfikuje się z obserwowalnym modelem zachowań, przy czym można przypuszczać, że intensywność identyfikacji ma bezpośredni związek z osobą modelowaną. Im większa bliskość więzi emocjonalnej z modelem zachowań, tym proces identyfikacji z nim przebiega silniej. W niniejszych badaniach ponad połowa respondentów nadal pozostaje $\mathrm{w}$ kontakcie $\mathrm{z}$ agresorem, mieszka wspólnie lub tworzy związek partnerski oparty na podobnych schematach współżycia interpersonalnego. Osoby te pozostają pod silnym wpływem doświadczeń z przeszłości, nie potrafiąc przerwać znanego sobie wzorca wchodzenia w relacje i rozwijania ich. Co więcej, można przypuszczać, że poza społecznym wyuczeniem się, zachodzi tu zjawisko agresji przemieszczonej. W prezentowanych badaniach blisko połowa osób doświadczających przemocy w dzieciństwie, aktualnie sama jest agresorem wobec innych. Wspomniany fenomen polega na skierowaniu odwzajemnianej agresji na osobę lub obiekt inny niż ten, w stosunku do którego pragnie się rewanżu [14]. W perspektywie czasu praca terapeutyczna z ofiarami przemocy domowej stwarza okazję do przeciwdziałania zjawisku wyuczonej bezradności oraz powielania destrukcyjnych wzorców rodzinnych, a świadomość psychologicznych konsekwencji stosowania przemocy wobec najmłodszych, pozwala mieć nadzieję na optymalizację działań zapobiegających rozpowszechnianiu tego typu patologii.

\section{WNIOSKI}

1. Osoby $\mathrm{z}$ wysokim poziomem cechy lęku znacząco częściej niż osoby z niskim poziomem cechy lęku doświadczały w dzieciństwie przemocy (fizycznej i psychicznej).

2. Przemoc doświadczana w dzieciństwie częściej przybiera formę opresji psychicznej aniżeli fizycznej.
3. Wysoki poziom lęku jako cechy znacząco liczniej wiązał się ze stosowaniem przemocy przez ojca $(\mathrm{p}<0.01)$.

4. Dominujące w momencie doznawania przemocy uczucie lęku i bezsilności znacznie liczniej dotyczy osób $\mathrm{z}$ wysokim poziomem cechy lęku, a z czasem w tej grupie osób utrwala się w postaci stale obecnego poczucia bezradności $(\mathrm{p}<0.05)$.

5. Osoby $\mathrm{z}$ wysokim poziomem cechy lęku znacząco liczniej nadal doświadczają przemocy, mieszkają ze sprawcami przemocy i stosują przemoc wobec innych $(\mathrm{p}<0.05)$.

\section{Conflict of interest}

The authors have declared no conflict of interest.

\section{References:}

1. KGP http://www.statystyka.policja.pl/portal/st/944/50863/ Przemoc_w_rodzinie.html. 2011.

2. Wójcik, Sz. Przemoc fizyczna wobec dzieci. Dziecko Krzywdzone, 2012; 2(39): 7-28.

3. Kempe, H.R., Kempe, C.H.: Assessing Family Pathology. W: Helfer R.E., Kempe R. red., Child Abuse and Neglect. The Family and Community. Cambridge; Mass Ballinger: 1976. s. 136-138.

4. Przetacznik-Gierowska, M., Tyszkowa, M. Psychologia rozwoju człowieka, T. 1. Warszawa; Wydawnictwo Naukowe PWN: 2000.

5. Brańka, Z. Przemoc $w$ rodzinie wobec dziecka jako czynnik społeczno-pedagogicznego nieprzystosowania uczniów, T. 2. Kraków; Oficyna Wydawnicza „Text”: 2006.

6. Miller, A. Gdy runą mury milczenia. Warszawa; Media Rodzina: 2006.

7. Martin, S.L., Kilgallen, B., Dee, D.L., Dawson, S., Campbell, J. Women in a Prenatal Care/Substance Abuse Treatment Program: Links Between Domestic Violence and Mental Health. Maternal and Child Health Journal, 1998; 2(2): 85-94.

8. Oatley, K., Jenkins, J.M. Zrozumieć emocje. Warszawa; Wydawnictwo Naukowe PWN: 2005.

9. Jouriles, E.N., Brown, A.S., McDonald, R., Rosenfield, D., Leahy, M.M., Silver, Ch. Intimate Partner Violence and Preschoolers' Explicit Memory Functioning. Journal of Family Psychology, 2008; 22(3): 420-428.

10. Spielberger, C.D., Strelau J., Tysarczyk, M. i Wrześniewski, K. Inwentarz Stanu i Cechy Lęku STAI. Warszawa; Wyd. PTP: 1987.

11. Kendall, P.C. Zaburzenia okresu dzieciństwa i adolescencji. Gdańsk; Gdańskie Wydawnictwo Psychologiczne: 2004.

12. Bandura, A., Walters, R.H. Agresja w okresie dorastania (przekład z j. ang. Cz. Czapow). Warszawa; PWN: 1968.

13. Eron, L.D. Parent-Child Interaction, Television Violence, and Aggression of Children. American Psychologist, 1987; 37(2): 197-211.

14. Bandura, A. Psychological mechanisms of aggression [w:] Geen, R.G., Donnerstein, E.I. (red.). Aggression: Theoretical and Empirical Reviews, T.1. NewYork; Academic Press: 1983, s. 1-40.

\section{Correspondence address \\ Bernarda Bereza \\ Katedra Psychologii Klinicznej KUL;}

Otrzymano: 28.11.2017

Zrecenzowano:19.12.2017, 26.12.2017, 30.01.2018

Przyjęto do druku: 31.01.2018 